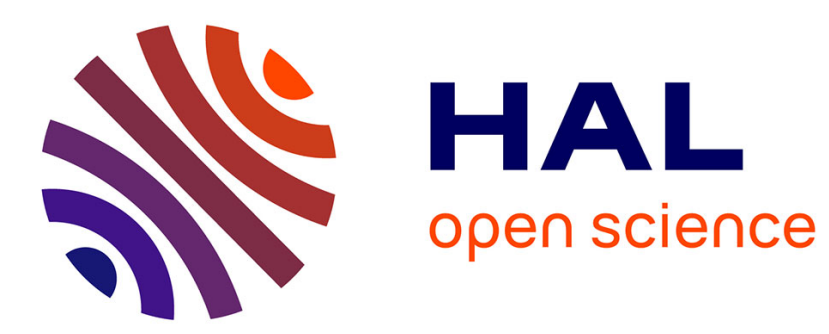

\title{
Recruitment of tree species in mixed selection and irregular shelterwood forest stands
}

Klopcic, Boncina

\section{To cite this version:}

Klopcic, Boncina. Recruitment of tree species in mixed selection and irregular shelterwood forest stands. Annals of Forest Science, 2012, 69 (8), pp.915-925. 10.1007/s13595-012-0224-1. hal00930873

\section{HAL Id: hal-00930873 \\ https://hal.science/hal-00930873}

Submitted on 1 Jan 2012

HAL is a multi-disciplinary open access archive for the deposit and dissemination of scientific research documents, whether they are published or not. The documents may come from teaching and research institutions in France or abroad, or from public or private research centers.
L'archive ouverte pluridisciplinaire HAL, est destinée au dépôt et à la diffusion de documents scientifiques de niveau recherche, publiés ou non, émanant des établissements d'enseignement et de recherche français ou étrangers, des laboratoires publics ou privés. 


\title{
Recruitment of tree species in mixed selection and irregular shelterwood forest stands
}

\author{
Matija Klopcic • Andrej Boncina
}

Received: 26 March 2012 / Accepted: 24 June 2012 / Published online: 24 July 2012

(C) INRA / Springer-Verlag France 2012

\begin{abstract}
- Context Recruitment is an important process in forest stand dynamics, especially in uneven-aged stands. Continuous recruitment is a prerequisite for diverse, uneven-aged silvicultural systems, but patterns may vary significantly.

- Aims The main goals of the study were to examine the recruitment of the main tree species in selection and irregular shelterwood stands in silver fir-European beech-Norway spruce forests and to determine the main predictors of the recruitment occurrence.

- Methods Data from 5,486 permanent inventory plots were used to study recruitment of saplings into the tree layer (diameter at breast height $\geq 10 \mathrm{~cm}$ ).

- Results Recruitment rate differed significantly between selection (7.6 trees $\mathrm{ha}^{-1}$ year $^{-1}$ ) and irregular shelterwood (26.1 trees ha ${ }^{-1}$ year $^{-1}$ ) stands. Shade-tolerant fir and beech recruited with higher probability in selection stands, while light-dependent sycamore recruited with higher probability in irregular stands. In addition, forest types, soil $\mathrm{pH}$, stand basal area, mean diameter, and the basal area of the same tree species with respect to recruitment were found to be important predictors of recruitment occurrence.

- Conclusions The application of different uneven-aged silvicultural systems and their forms makes it possible to
\end{abstract}

Handling Editor: Douglass Jacobs

Contributions of the co-authors The first author's contribution to the paper was in preparing the data, runing the data analysis, processing results, and writing the paper.

The last author's contribution was in producing the research idea, coordinating and supervising the work, and editing the final version of the paper.

M. Klopcic $(\bowtie) \cdot$ A. Boncina

Department of Forestry and Renewable Forest Resources,

University of Ljubljana, Biotechnical Faculty,

Vecna pot 83,

1000 Ljubljana, Slovenia

e-mail: matija.klopcic@bf.uni-lj.si considerably influence the future tree species composition of uneven-aged forests.

Keywords Ingrowth · Uneven-aged forests · Fir-beechspruce forests $\cdot$ Natural regeneration $\cdot$ Saplings $\cdot$ Binary logistic regression

\section{Introduction}

Stand dynamics can be described by a number of processes, including regeneration, tree growth, recruitment, tree species replacement, tree mortality, and changes in structure and composition (Oliver and Larsen 1996). Recruitment is generally defined as a process by which young individuals are added to the population, while in silviculture, recruitment is understood as the process by which saplings or young trees overgrow a certain threshold value (Lexerød and Eid 2005). Usually, recruitment occurrence and recruitment rate are studied; in our study, recruitment rate is defined as the number of trees reaching or exceeding a diameter measurement threshold of $10 \mathrm{~cm}$ over a certain period of time. Recruitment rate is an important stand parameter for uneven-aged forest management (Duc 1991; Schütz 2001, 2006; Yoshida et al. 2006) since it reveals different processes in uneven-aged stands, such as changes in structure and composition, which may demonstrate the adequacy of past forest management and suggest options for the maintenance of uneven-aged structure in forest stands.

In Central Europe, the selection and irregular shelterwood systems are the most widespread among unevenaged silvicultural systems. Their use results in diverse, uneven-aged horizontal stand structures. The selection silvicultural system, including single tree (traditionally called the "plenter" system) and group selection systems, aims to establish forest stands (hereafter selection stand type) in 
which trees of different ages and dimensions create vertically and horizontally uneven structures in a small forest area, with no obvious boundaries between stands (Schütz 2001; Diaci 2006). Selection stands are composed of trees of different sizes (height and diameter at breast height (dbh)) and ages growing together in a small area, with understory trees capable of recruitment to the upper-story when light conditions are favorable (Boncina 2011). Groups of samesized trees (cohorts) typically do not exceed an area of 0.05 0.10 ha. The irregular shelterwood system (also called "verfeinerte Femelschlag"; Leibundgut 1952) has been defined as "a system of successive regeneration fellings with a long and indefinite regeneration period, producing young crops of somewhat uneven-aged type" (Mathews 1999) (hereafter irregular stand type). The intent of this system is to create multispecies cohorts by adapting canopy openings to the light requirements of desired tree species (Diaci 2006; Raymond et al. 2009). Different-sized (even-aged) cohorts are characteristic for different types of irregular shelterwood systems (Raymond et al. 2009), where horizontal structure may vary from a fine-grained (cohorts of $0.05-0.25$ ha) to a coarsegrained structure (cohorts of $0.25-1 \mathrm{ha}$ ). Usually, differences in mean stand height or dominant stand diameter between cohorts can be recognized and different developmental stages can be distinguished, e.g., regeneration, thicket stage, pole stage, mature stage, and rejuvenation stage (Diaci 2006).

Continuous and abundant regeneration is a prerequisite for both systems (Mathews 1999). The tree species composition of the seedling layer, or even the sapling layer, may be noticeably different from that of the subsequent mature stand. Light conditions greatly influence which tree species, or individuals of the same species, grow faster and recruit from the regeneration layer into the canopy (e.g., Collet et al. 2001; Stancioiu and O'Hara 2006; Petritan et al. 2007). The availability and composition of light in a stand are significantly related to canopy structure; both diffuse and direct light intensities increase with gap size (e.g., Rozenbergar et al. 2007). Smaller gaps promote the recruitment of shade-tolerant species, while larger gaps encourage the growth of more light-demanding species (Nagel et al. 2010). Therefore, it is thought that selection silvicultural systems promote shade-tolerant tree species, while the irregular shelterwood system offers greater possibilities for the growth and recruitment of intermediate and light-demanding tree species (e.g., Schütz 2001, 2006; Diaci 2006; Raymond et al. 2009).

In addition to canopy structure, some other stand parameters are relevant for the recruitment of tree species. In mixed forests in Norway (Lexerød 2005; Lexerød and Eid 2005), the recruitment occurrence and recruitment rate of the main tree species were found to be related to several stand parameters (e.g., stand height, stand density, tree species composition, stand structure). In contrast, Lundqvist
(2004) found no correlation between recruitment rate and stand volume or the number of small trees under the measurement threshold.

Recruitment patterns may vary between different forest types. Altitude, latitude, and vegetation type, which is an indication of soil fertility, moisture, and competition from herbs, were found to influence the probability of recruitment occurrence and the abundance of tree species recruitment in mixed, uneven-aged (Lexerød 2005) and young, even-aged stands in Norway (Lexerød and Eid 2005).

Large ungulates may influence the recruitment of tree species (Klopcic et al. 2010). Ungulates damage seedlings, saplings, and young trees through fraying, bark stripping, or browsing (Gill 1992). Damage often correlates with large ungulate densities. In Central Europe, this is particularly evident for palatable tree species such as silver fir (Abies alba Mill.; e.g., Motta, 1996) or sycamore (Acer pseudoplatanus L.). Because damage to young trees may cause their mortality, large ungulates may influence the tree species composition and height distribution of the regeneration, and consequently the composition and abundance of recruitment.

The main focus of our study was on examining the recruitment of the main tree species in selection and irregular stands in mixed silver fir-European beech-Norway spruce forests: (1) European beech (Fagus sylvatica L.; hereafter, beech): a lateral and vertical shade-tolerant species having rather slow height growth in its juvenile stage, faster growth in subsequent stages, and high competitiveness on the analyzed sites; (2) silver fir (hereafter, fir): a lateral and vertical shade-tolerant species which has relatively slow height growth and high competitiveness in natural conditions but is highly susceptible to large ungulate impact; (3) Norway spruce (Picea abies (L.) Karst.; hereafter, spruce): a species which tolerates lateral shade but grows better in open spaces, and which prefers acidic sites with colder climate; and (4) sycamore: a light-demanding species having fast juvenile height growth and a generally lower competitiveness. In addition, we wanted to determine the predictors of recruitment occurrence among stand, site, forest management, and wildlife variables. We tested several hypotheses: (1) The recruitment rate is higher in irregular stands than in selection stands; (2) shade-tolerant tree species recruit better in selection stands, while shade-intolerant tree species recruit more abundantly in irregular stands; (3) forest types within the mixed fir-beech-spruce forests significantly influence the recruitment occurrence of the analyzed tree species.

\section{Material and methods}

\subsection{Study area}

Our study was restricted to mixed fir-beech-spruce forests on carbonate and noncarbonate bedrock in Slovenia (Fig. 1), 
Fig. 1 Distribution of three types of mixed fir-beech-spruce forests in Slovenia

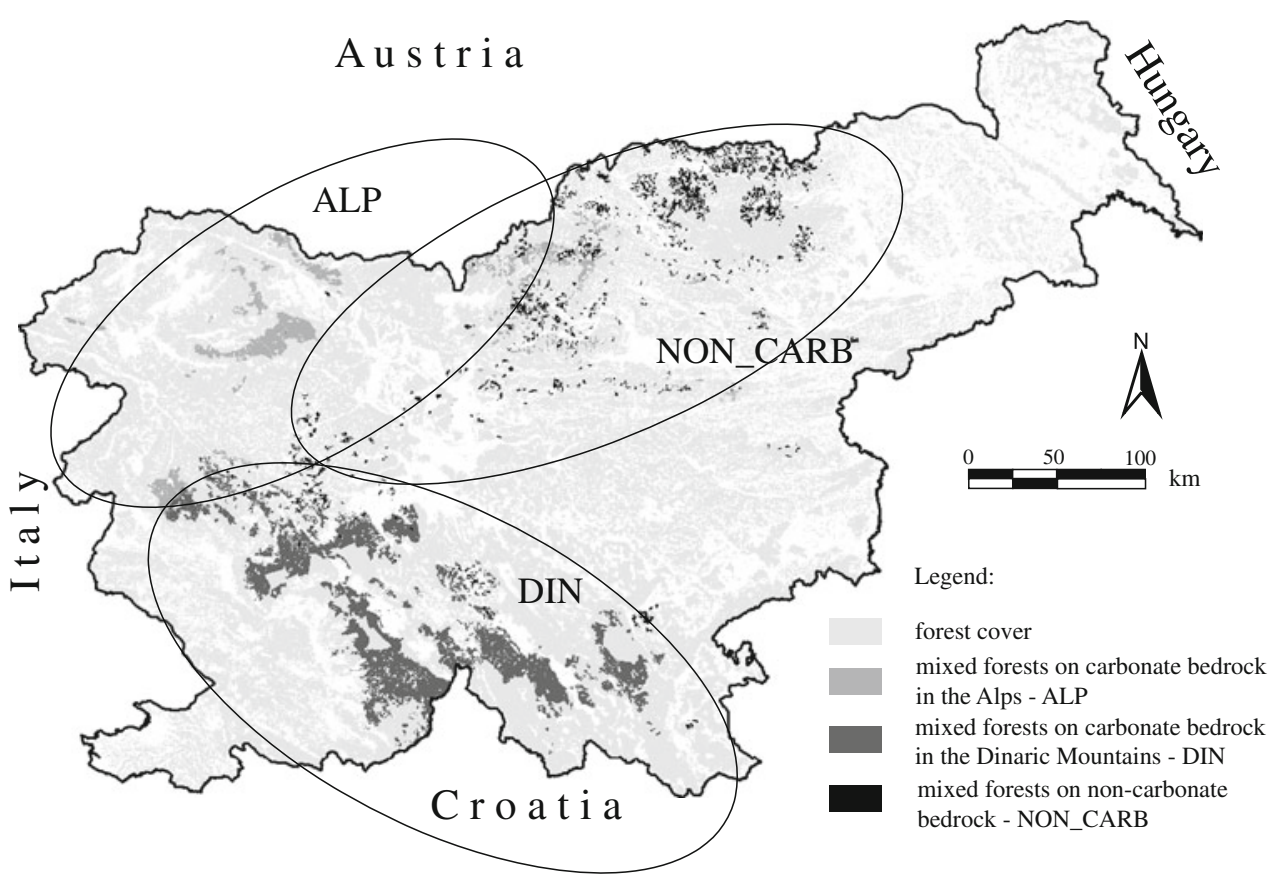

representing $18 \%$ of the total forest cover (SFS 2010). These forests have been managed by the principles of closeto-nature silviculture for the past 50 years, which mainly utilized the irregular shelterwood and also selection silvicultural systems. Consequently, most of these forests are of irregular and selection stand structures. Within the mixed fir-beech-spruce forests, three main forest types can be identified: mixed fir-beech-spruce forests on carbonate bedrock in the Alps (ALP), mixed fir-beech-spruce forests on carbonate bedrock in the Dinaric Mountains (DIN), and mixed firspruce forests on noncarbonate bedrock (NON_CARB) present mainly outside of the Alps and the Dinaric Mountains. These forest types not only differ with respect to many site conditions and stand characteristics (Table 1), but also with respect to forest management history (e.g., Ficko et al. 2011).

\subsection{Data acquisition and database creation}

Data from several regional forest inventories were used in the study (SFS 2010). A forest inventory in Slovenia is done for the entire forest area regardless of its ownership. It is based on a combination of two interwoven methods: a detailed field survey of forest stands (i.e., a forest stand delineation with an assessment of some stand parameters for each stand) and a permanent sampling plot method (i.e., plot area $=200 \mathrm{~m}^{2}$; plots are located mainly on a $250 \times 500 \mathrm{~m}$ grid, but in some areas, other grids are also used (e.g., $200 \times$ $200 \mathrm{~m}$ ); tree measurement threshold is defined at $10 \mathrm{~cm}$ in $\mathrm{dbh}$; for every tree, polar coordinates are determined with an azimuth and a distance from the plot center, dbh is measured, and tree species, social status, timber quality, and damage to the trunk and/or crown are visually assessed).
Stand type (selection or irregular) is determined for each plot at every measurement. Because of that, a stand history is known for each plot at least for the period between the last two consecutive forest inventories.

A total of 5,486 plots, in which two consecutive forest inventories were made at a 10-year interval, were included in our analysis. This enabled the calculation of the recruitment rate, which is defined as the number of trees that attain the measurement threshold of $10 \mathrm{~cm}$ per hectare per year. From silvicultural and forest management perspectives, recruitment in irregular stands is important only in cohorts of young developmental stages, therefore only plots in the regeneration, and thicket and pole stage stands were included in the analysis. In such cohorts, the height and diameter growth of young individuals is intensive, but may noticeably differ between individuals and between tree species. Consequently, the vertical stratification of individuals within each cohort is intensive and results in the establishment of a canopy layer. In cohorts of mature developmental stage, however, the vertical stratification of trees is rather complete. Additional recruited trees are usually overtopped by the canopy and remain in the understory. Therefore, an investigation of recruitment in cohorts of mature stage is less relevant and plots were excluded from the analysis. In contrast, all plots in the selection stand type were selected for investigation. Since vertical (and horizontal) structure of a selection stand is uneven over a small forest area, recruitment is important on the entire area of selection stands.

In order to identify predictors of recruitment occurrence in stands, a database of information obtained mainly from Slovenian Forest Service databases (SFS 2010) was constructed and included relevant independent variables of stand 
Table 1 Site and stand characteristics of forest stands in the analyzed forest types, derived from permanent sample plots (mean values with first $\left(\mathrm{Q}_{25}\right)$ and third $\left(\mathrm{Q}_{75}\right)$ quartiles are shown)

\begin{tabular}{|c|c|c|c|c|c|c|c|c|c|}
\hline & \multicolumn{9}{|c|}{ Forest type $^{\mathrm{a}}$} \\
\hline & \multicolumn{3}{|l|}{ ALP } & \multicolumn{3}{|l|}{ DIN } & \multicolumn{3}{|c|}{ NON_CARB } \\
\hline & $\mathrm{Q}_{25}$ & Mean & $\mathrm{Q}_{75}$ & $\mathrm{Q}_{25}$ & Mean & $\mathrm{Q}_{75}$ & $\mathrm{Q}_{25}$ & Mean & $\mathrm{Q}_{75}$ \\
\hline Number of plots & & 1,033 & & & 3,985 & & & 468 & \\
\hline \multicolumn{10}{|l|}{ Site conditions } \\
\hline Altitude (m a.s.1.) & 978 & 1,047 & 1,200 & 690 & 817 & 1,000 & 470 & 603 & 750 \\
\hline Inclination $\left(^{\circ}\right)$ & 14 & 21 & 27 & 11 & 16 & 22 & 16 & 23 & 31 \\
\hline Annual temperature $\left({ }^{\circ} \mathrm{C}\right)$ & 5.00 & 5.65 & 6.00 & 6.00 & 6.74 & 7.00 & 7.00 & 7.57 & 8.00 \\
\hline Annual precipitation (mm) & 1,800 & 2,031 & 2,200 & 1,605 & 1,835 & 1,980 & 1,212 & 1,373 & 1,432 \\
\hline Soil pH & 4.70 & 5.15 & 5.70 & 5.00 & 5.40 & 5.70 & 3.70 & 4.29 & 4.50 \\
\hline Soil depth & 39.0 & 41.9 & 42.0 & 39.0 & 53.3 & 64.0 & 48.0 & 60.8 & 71.0 \\
\hline \multicolumn{10}{|l|}{ Stand characteristics } \\
\hline Proportion of plots in selection stands & & 39.2 & & & 63.3 & & & 50.4 & \\
\hline Stand volume $\left(\mathrm{SV} ; \mathrm{m}^{3} \mathrm{ha}^{-1}\right)$ & 193 & 310 & 416 & 220 & 335 & 436 & 195 & 313 & 534 \\
\hline Stand basal area $\left(\mathrm{m}^{2} \mathrm{ha}^{-1}\right)$ & 20.7 & 30.8 & 40.4 & 21.6 & 30.0 & 38.0 & 19.4 & 27.8 & 36.0 \\
\hline Proportion of silver fir (\% of SV) & 0.0 & 15.0 & 25.4 & 0.0 & 31.4 & 54.3 & 0.0 & 32.3 & 57.6 \\
\hline Proportion of Norway spruce (\%) & 9.1 & 36.6 & 58.5 & 0.0 & 17.0 & 28.5 & 10.8 & 32.8 & 53.0 \\
\hline Proportion of European beech (\%) & 12.1 & 39.2 & 63.0 & 11.9 & 39.2 & 63.3 & 0.0 & 11.3 & 14.4 \\
\hline Proportion of sycamore (\%) & 0.0 & 3.1 & 2.4 & 0.0 & 4.7 & 5.6 & 0.0 & 3.8 & 0.0 \\
\hline
\end{tabular}

${ }^{\text {a }}$ Forest type: $A L P$ mixed fir-beech-spruce forests on carbonate bedrock in the Alps, $D I N$ mixed fir-beech-spruce forests on carbonate bedrock in the Dinaric Mountains, NON_CARB mixed fir-spruce forests on mainly noncarbonate bedrock

characteristics, site conditions, forest management, and wildlife component (Table 2). Although it was assumed that recruitment occurrence depends mainly on stand characteristics, forest management variables, large ungulate densities, and site conditions may also be relevant. Some soil characteristics and competition from ground vegetation can be indirectly described by vegetation types (i.e., phytosociological associations), which are stratified into the three forest types included in our analysis (Fig. 1; SFS 2010). To estimate large ungulate impact on recruitment rate, the modified ungulate density index (UDI'), adapted after Motta (1996), was included in the analysis. UDI' was calculated as a weighted sum of local densities of large ungulates (see Table 2): red deer, fallow deer, mouflon, chamois, and roe deer. Estimations of local densities were derived from data on annual harvest and loss (roadkill, found dead animals, etc.) for the period 2004-2008, which were spatially referenced with a resolution of $1 \times 1 \mathrm{~km}$ (e.g., Jerina 2012).

\subsection{Data processing}

Because of the inequality of variances between groups, basic statistical analyses were done using the nonparametric MannWhitney $U$ test for two independent samples (MW). To devise models of recruitment occurrence, binary logistic regression was applied. The recruitment rate was transformed into a dichotomous (binary) dependent variable with a value of 1 when at least one recruited tree was registered on a plot.

In the preliminary analysis of the data, a set of independent variables was analyzed to detect multicolinearity and to obtain a set of variables to be included in the modeling procedure (Guisan and Zimmermann 2000). Therefore, Pearson's correlation coefficients $(r)$ were calculated between continuous independent variables, and only one variable for pairs with $r>0.60$ was included in the procedure. Next, contingency tables with an $\chi^{2}$ test (for categorical variables) and two sample $t$ tests (for continuous variables) between a particular independent variable and the (binary) dependent variable were applied. If the $p$ value was less than 0.25 , the variable was accepted as a candidate for the modeling procedure.

The selected set of independent variables was included in a forward-stepwise modeling procedure based on the maximum likelihood criterion with a maximum iteration number of 20. When the model was obtained, the variance inflation factor (VIF), calculated as $1 /\left(1-R^{2}\right)$, was compared to the critical value of 10 (Allison 1999). $R^{2}$ was acquired in a linear regression for continuous predictors or in a logistic regression for nominal predictors using one predictor as a dependent variable and all others as independent ones. The predictor was kept in the model only if the VIF was lower than the critical value. Goodness-of-fit of the calculated 
Table 2 Independent variables included in the database

\begin{tabular}{|c|c|c|c|}
\hline & Variable & Description & Mod.proc. ${ }^{\mathrm{a}}$ \\
\hline \multirow[t]{5}{*}{ Stand variables } & BA_SP & Basal area of the same species with respect to recruitment at first forest inventory $\left(\mathrm{m}^{2} \mathrm{ha}^{-1}\right)$ & Yes \\
\hline & N_OLD & Number of trees at first forest inventory $\left(\mathrm{N} \mathrm{ha}^{-1}\right)$ & No \\
\hline & BA_OLD & Stand basal area at first forest inventory $\left(\mathrm{m}^{2} \mathrm{ha}^{-1}\right)$ & Yes \\
\hline & SV_OLD & Stand volume at first forest inventory $\left(\mathrm{m}^{3} \mathrm{ha}^{-1}\right)$ & No \\
\hline & $\mathrm{DBH}_{\mathrm{BA}}$ & Quadratic mean diameter $(\mathrm{cm})$ & Yes \\
\hline \multirow[t]{11}{*}{ Site variables } & FOR_TYPE & $\begin{array}{l}\text { Forest type } \\
\text { (1) mixed fir-beech-spruce forests on carbonate bedrock in the Alps-ALP }\end{array}$ & Yes \\
\hline & & (2) mixed fir-beech-spruce forests on carbonate bedrock in the Dinaric Mountains-DIN; & \\
\hline & & (3) mixed fir-spruce forests on mainly noncarbonate bedrock-NON_CARB & \\
\hline & ALT & Altitude (m a.s.l.) & Yes \\
\hline & INC & Inclination $\left({ }^{\circ}\right)$ & Yes \\
\hline & ASP & Aspect $(1, \mathrm{~N} ; 2, \mathrm{NE} ; \ldots ; 9$, plane $)$ & Yes \\
\hline & TOP & Topography $(0$, slope + ridge; 1 , plane + foot of the hills $)$ & Yes \\
\hline & $\mathrm{pH}$ & Soil $\mathrm{pH}$ & Yes \\
\hline & SDEP & Soil depth $(\mathrm{cm})$ & Yes \\
\hline & TEMP & Mean annual temperature $\left({ }^{\circ} \mathrm{C}\right)$ & No \\
\hline & PREC & Mean annual precipitation (mm) & Yes \\
\hline \multirow{3}{*}{$\begin{array}{l}\text { Forest } \\
\text { management } \\
\text { variables }\end{array}$} & ST_TYPE & Stand type (1, selection; 0 , irregular) & Yes \\
\hline & A_CUT & Annual timber harvest $\left(\mathrm{m}^{3} \mathrm{ha}^{-1}\right.$ year $\left.^{-1}\right)$ & No \\
\hline & A_MORT & Annual total mortality of trees $\left(\mathrm{m}^{3} \mathrm{ha}^{-1}\right.$ year $\left.^{-1}\right)$ & Yes \\
\hline Wildlife variable & $\mathrm{UDI}^{\prime}$ & $\begin{array}{l}\text { Modified Ungulate Density Index (adapted after Motta }(1996): \mathrm{UDI}^{\prime}=\text { red deer density }+1 / 2 \\
\text { fallow deer density }+1 / 4 \text { chamois density }+1 / 4 \text { mouflon density }+1 / 5 \text { roe deer density) }\end{array}$ & Yes \\
\hline
\end{tabular}

${ }^{a}$ Modeling procedure: indicates variables that were candidates for the probability model and were included in the stepwise binary logistic regression modeling procedure

models was tested with the adjusted $D^{2}$ values (Guisan and Zimmermann 2000), calculated as shown in Eq. 1:

adjusted $D^{2}=1-[(n-1) /(n-p)] \times\left[1-D^{2}\right]$

where $n$ represents the number of observations, $p$ the number of predictors in the model, and $D^{2}$ the deviance reduction, calculated as shown in Eq. 2:

$D^{2}=($ null deviance - residual deviance $) /$ null deviance

The models were calculated separately for the main tree species: fir, spruce, beech, and sycamore. To interpret the results, the predicted probability of recruitment occurrence was calculated as follows in Eq. 3:

$p=\frac{\exp \left(\beta_{0}+\beta_{1} x_{1}+\beta_{2} x_{2}+\ldots+\beta_{n} x_{n}\right)}{1+\exp \left(\beta_{0}+\beta_{1} x_{1}+\beta_{2} x_{2}+\ldots+\beta_{n} x_{n}\right)}$

where $p$ is the probability of recruitment occurrence, $\beta_{0} \ldots \beta_{n}$ are the parameters of the linear model, and $x_{1} \ldots x_{n}$ are predictors.

\section{Results}

3.1 Recruitment rate in selection and irregular stand types

The mean recruitment rate significantly differed between the observed stand types (MW: standardized test statistic $=$ $-17,406, p<0.001)$ and averaged 7.6 trees $^{h^{-1}}$ year $^{-1}$ in selection stands and 26.1 trees $\mathrm{ha}^{-1}$ year $^{-1}$ in irregular stands (Table 3). Recruitment rate data was highly variable in both stand types; the coefficient of variation was 145 and $180 \%$ for selection and irregular stands, respectively.

Recruitment rate of all the analyzed tree species was higher in irregular stands; the differences were significant for fir (MW: standardized test statistic $=2,689, p=0.007$ ), spruce (MW: standardized test statistic $=-13,873, p<$ 0.001 ), beech (MW: standardized test statistic $=-7,118$, $p<0.001$ ), and sycamore (MW: standardized test statistic $=-8,757, p<0.001)$. Also, the proportion of plots with registered recruitment was higher in irregular stands than in selection stands for spruce, beech, and sycamore, but not for fir, indicating that fir may recruit with higher probability in selection stands. 
Table 3 Recruitment rate of tree species in selection and irregular stand type

Recruitment rate
$\left(\mathrm{N} \mathrm{ha}^{-1}\right.$ year $\left.^{-1}\right)$

No. obs. ${ }^{a} \quad$ Prop. obs. rec. $^{b} \quad$ All obs. ${ }^{c} \quad$ Obs. Rec. $^{d}$

\begin{tabular}{llcll}
\hline \multicolumn{5}{l}{ Selection stands } \\
Fir & 3,163 & 19.5 & 1.5 & 7.8 \\
Spruce & 3,163 & 16.2 & 1.9 & 11.7 \\
Beech & 3,163 & 38.0 & 3.6 & 9.4 \\
Sycamore & 3,163 & 2.9 & 0.2 & 4.2 \\
All species & 3,163 & 58.9 & 7.6 & 13.0 \\
& Irregular stands & & \\
Fir & 2,323 & 15.7 & 3.1 & 19.8 \\
Spruce & 2,323 & 29.9 & 12.4 & 41.6 \\
Beech & 2,323 & 43.3 & 7.3 & 16.9 \\
Sycamore & 2,323 & 8.2 & 0.8 & 11.3 \\
All species & 2,323 & 70.2 & 26.1 & 37.2 \\
\hline
\end{tabular}

${ }^{a}$ Number of observations

${ }^{\mathrm{b}}$ Proportion of observations with registered recruitment

${ }^{\mathrm{c}}$ All observations

${ }^{\mathrm{d}}$ Observations with registered recruitment

At least one recruited tree per plot was registered in 58.9 and $70.2 \%$ of plots in selection and irregular stands, respectively. However, these proportions varied noticeably depending on the particular tree species and were highest for beech and lowest for sycamore in both stand types. No recruited trees were registered in $41.1 \%$ of the plots in selection stands and $29.8 \%$ of the plots in irregular stands.

3.2 Recruitment occurrence probability models for the main tree species

From the set of independent variables, four to nine predictors were included in the models of recruitment occurrence for fir, spruce, beech, and sycamore, respectively (Table 4). The VIF analyses retained all predictors in the models. The adjusted $D^{2}$ value was highest for the spruce recruitment occurrence model, lower for the fir and sycamore models, and very low for the beech model.

The analysis showed that stand type had an important influence on the recruitment occurrence of the majority of the main tree species, spruce being an exception. The probability of fir recruitment occurrence in irregular stands was lower by a factor of 0.77 than that in selection stands. Similarly, this factor was 0.83 for beech. In contrast, the probability of sycamore recruitment occurrence was higher in irregular stands than in selection stands by a factor of 1.56 .
Forest type had a significant influence on the recruitment occurrence of fir, spruce, and beech. The probability of fir recruitment occurrence in DIN compared with NON_CARB was lower by a factor of 0.47 , while the same factor in ALP amounted to 0.81 . In contrast, the probability of beech recruitment occurrence in DIN compared with NON_CARB was higher by a factor of 2.75 and even higher in ALP (2.96). The probability of spruce recruitment occurrence in DIN was lower in comparison with NON_CARB by a factor of 0.92, but higher in ALP compared with NON_CARB by a factor 1.34 .

Since forest type was found to be an important predictor of recruitment occurrence, the recruitment rate within forest types was additionally analyzed in detail. Significant differences between irregular and selection stands in the recruitment rate of all tree species were assessed in ALP and DIN (all $p<0.001)$. In NON_CARB, differences in the mean recruitment rate were significant only for spruce $(p<$ 0.001). In ALP, less shade-tolerant spruce largely predominated in the recruitment of irregular stands, while beech was the dominant tree species in selection stands (Fig. 2). Fir recruited more abundantly in irregular stands than in selection stands. In DIN, beech was the most prevalent tree species in the recruitment in both stand types. Fir recruitment rate was higher in selection stands than in irregular stands, but significantly lower than that for spruce and beech in both stand types (both $p<0.001$ ). In NON_CARB, conifers predominated in the recruitment (spruce in irregular stands and fir in selection stands). In all forest types, shade-intolerant sycamore recruited more abundantly in irregular stands compared with selection stands.

Among site variables, soil $\mathrm{pH}$ had the greatest influence on the recruitment occurrence of fir, spruce, and beech, which were all more likely to occur on sites with lower soil $\mathrm{pH}$. Altitude and mean annual precipitation had only minor influence on fir, spruce, and beech recruitment occurrence.

Stand variables were found to be significant predictors in the probability models. With respect to recruitment, the basal area of the same tree species in a stand (BA_SP) significantly increased the probability of its recruitment occurrence in a plot. BA_SP had the greatest influence in the sycamore model, while it had the least influence in the beech model. Stand basal area (BA_OLD) and quadratic mean diameter $\left(\mathrm{DBH}_{\mathrm{BA}}\right)$ also had an important influence on the recruitment occurrence of all analyzed tree species. The probability of recruitment occurrence in all models decreased with increasing stand basal area. However, the predicted probabilities in regard to a stand basal area differed between tree species and stand type (Fig. 3). In general, the predicted probabilities decreased with increasing basal area, but the predicted probabilities for fir recruitment occurrence in selection stands did not vary a great deal 
Table 4 Site conditions, stand characteristics, forest, and wildlife management factors in relations to the recruitment occurrence of different tree species (only significant variables are shown)

\begin{tabular}{|c|c|c|c|c|c|c|c|c|}
\hline \multirow[t]{2}{*}{ Variable } & \multicolumn{2}{|l|}{ Fir } & \multicolumn{2}{|l|}{ Spruce } & \multicolumn{2}{|l|}{ Beech } & \multicolumn{2}{|c|}{ Sycamore } \\
\hline & $\beta$ & $p$ & $\beta$ & $p$ & $\beta$ & $p$ & $\beta$ & $p$ \\
\hline Intercept & 1.994 & $<0.001$ & 2.447 & $<0.001$ & -0.007 & 0.977 & -1.680 & $<0.001$ \\
\hline BA_SP & 0.083 & $<0.001$ & 0.103 & $<0.001$ & 0.010 & 0.005 & 0.133 & $<0.001$ \\
\hline BA_OLD & -0.043 & $<0.001$ & -0.099 & $<0.001$ & -0.022 & $<0.001$ & -0.046 & $<0.001$ \\
\hline $\mathrm{DBH}_{\mathrm{BA}}$ & -0.030 & $<0.001$ & -0.020 & $<0.001$ & -0.028 & $<0.001$ & -0.026 & 0.001 \\
\hline \multicolumn{9}{|l|}{ FOR_TYPE } \\
\hline ALP & -0.209 & 0.243 & 0.296 & 0.071 & 1.086 & $<0.001$ & & \\
\hline DIN & -0.748 & $<0.001$ & -0.087 & 0.538 & 1.012 & 0.003 & & \\
\hline NON_CARB & 0 & & 0 & & 0 & & & \\
\hline ALT & 0.002 & $<0.001$ & 0.001 & 0.008 & 0.001 & $<0.001$ & & \\
\hline $\mathrm{pH}$ & -0.344 & $<0.001$ & -0.244 & $<0.001$ & -0.156 & $<0.001$ & & \\
\hline PREC & -0.001 & $<0.001$ & 0.001 & 0.002 & & & & \\
\hline \multicolumn{9}{|l|}{ ST_TYPE } \\
\hline SELECTION & 0 & & & & 0 & & 0 & \\
\hline IRREGULAR & -0.257 & 0.008 & & & -0.185 & 0.007 & 0.444 & 0.003 \\
\hline A_MORT & & & 0.013 & $<0.001$ & 0.008 & 0.002 & & \\
\hline $\mathrm{UDI}^{\prime}$ & -0.016 & 0.035 & & & -0.023 & $<0.001$ & & \\
\hline Adjusted $D^{2}$ & 0.137 & & 0.198 & & 0.059 & & 0.089 & \\
\hline
\end{tabular}

$(0.20-0.25)$ over the entire range of stand basal areas. Similarly, quadratic mean diameter $\mathrm{DBH}_{\mathrm{BA}}$ negatively influenced the probability of recruitment occurrence of all tree species. Such a result was expected since the probability of recruitment occurrence is typically higher when $\mathrm{DBH}_{\mathrm{BA}}$ is close to the measurement threshold value.

As the only wildlife variable included in the modeling procedure, the modified UDI' index showed only a minor influence on the probability of recruitment occurrence of fir and beech.

\section{Discussion}

In Europe, there is a lack of studies dealing with recruitment of saplings into the stand canopy. Even for some dominant or codominant tree species, there are, to our knowledge, no studies available. A possible reason for the lack of studies on recruitment is the orientation of research towards other relevant topics such as regeneration and growth, which are indeed both strongly related to recruitment. The investigation of recruitment demands
Fig. 2 Recruitment rates of the main tree species in irregular and selection stands of the analyzed forest types

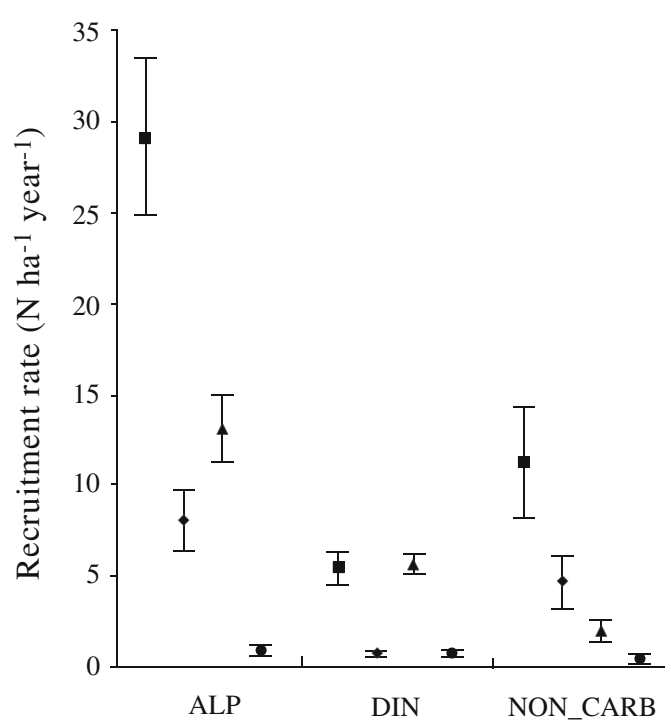

Irregular stands

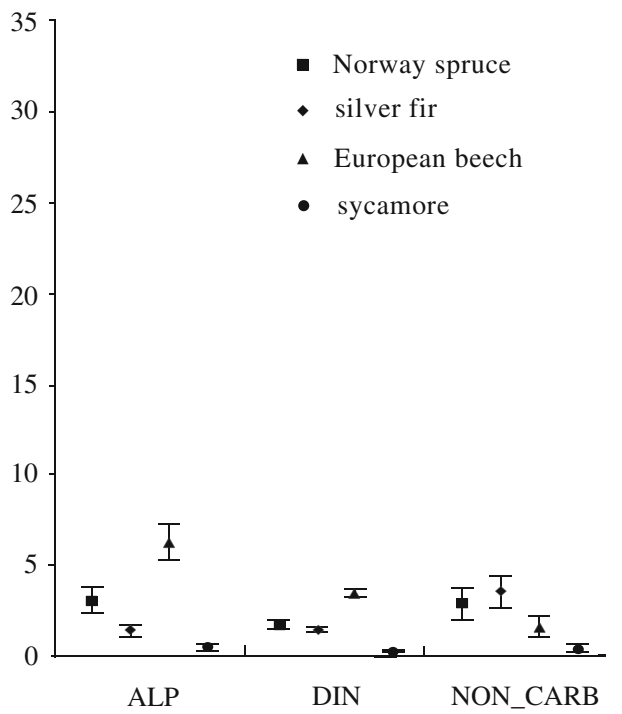

Selection stands 

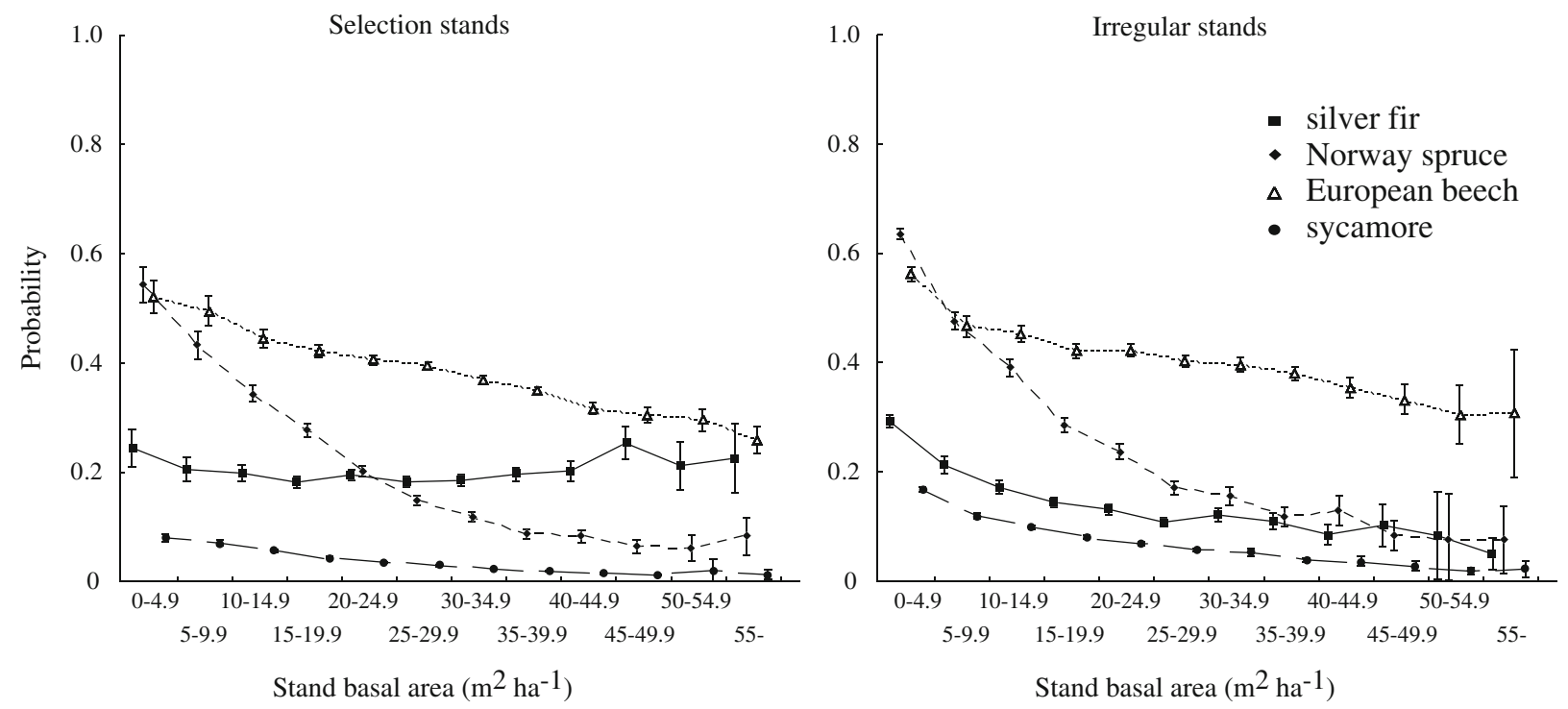

Fig. 3 Predicted probabilities of a recruitment occurrence of the analyzed tree species in regard to stand basal area

at least two consecutive measurements in the same study area with the time interval between them long enough to allow saplings to overgrow the measurement threshold. Such data may be gathered only in long-term experimental plots or provided by consecutive national or regional forest inventories.

Permanent sampling plot data, provided by several regional forest inventories in this study, enable analysis of various forest stand attributes (e.g., Brassel and Lischke 2001; Lexerød and Eid 2005). In this study, two simple parameters (recruitment rate and recruitment occurrence) were used for the analysis of the recruitment. Some other recruitment indices (e.g., the recruitment rate index adapted from Yoshida et al. 2006) were calculated and examined, but the results were similar and are therefore not shown here. A potential drawback of our analysis is that the small size of the plot $\left(200 \mathrm{~m}^{2}\right)$ makes a large part of it susceptible to conditions on the outside. This issue was particularly relevant for stand characteristics in the plot, but less so for the assessed site conditions. However, the large number of systematically distributed plots over a large forest area and the high number of recruited trees recorded (almost 17,000) may have largely contributed to a more accurate assessment of the recruitment rate and the reliable identification of influential factors (e.g., Brassel and Lischke 2001; Lexerød 2005).

The overall observed recruitment rates in selection and irregular stands were similar or higher than the reference values proposed by different authors. In plenter stands, Duc (1991) determined an average of 7.6 recruited trees $\mathrm{ha}^{-1}$ year ${ }^{-1}$ and proposed an interval of five to nine recruited trees $\mathrm{ha}^{-1}$ year ${ }^{-1}$ to maintain selection structure in montane mixed stands. Schäffer et al. (1930) proposed a recruitment of $1.5 \mathrm{~m}^{3} \mathrm{ha}^{-1}$ year ${ }^{-1}$, corresponding to approximately six trees per hectare per year, but at a measurement threshold of $17.5 \mathrm{~cm} \mathrm{dbh}$. Somewhat lower values of between three and seven trees per hectare per year were suggested by Schütz (1975), but at a measurement threshold of $15 \mathrm{~cm}$ dbh. Higher recruitment rates were observed in boreal coniferous forests, where, in two separate studies, recruitment reached 10 (Lundqvist 2004; a measurement threshold of $8 \mathrm{~cm} \mathrm{dbh}$ ) and 13 trees ha ${ }^{-1}$ year ${ }^{-1}$ (Lähde et al. 2002; a measurement threshold of $9 \mathrm{~cm} \mathrm{dbh}$ ), respectively. According to the referred values, and particularly those referred by Duc (1991), we can conclude that the average recruitment rate in the uneven-aged forest stands we analyzed was adequate to maintain uneven-aged stand structure in the long term.

Although the average recruitment rate in each stand type was sufficiently high, the large number of plots without any registered recruitment could jeopardize the maintenance of uneven-aged structures, especially in selection stands. However, this result could have been biased by the small size of the plot. If cohorts in (group) selection stands reach sizes $0.05-0.10$ ha, a plot size of 0.02 ha might be too small to register the recruited trees present in the cohorts. This is even more likely in irregular stands where the size of cohorts usually greatly exceeds $0.05-0.10$ ha.

Stand type was found to be a significant predictor in the models of fir, beech, and sycamore recruitment occurrence. Fir and beech recruitment occurred with higher probability in selection stands, but were found to be more abundant in the recruitment of irregular stands. Such contradictory results were to be expected since the densities of seedlings and saplings of all tree species are usually much higher in irregular stands than in selection stands (Diaci 2006) where poor light conditions cause mortality of seedlings and saplings and a reduction in the density of the regeneration 
(Petritan et al. 2007) and recruitment. However, the low light availability in selection stands promotes the regeneration occurrence, growth, and recruitment of shade-tolerant fir and beech (Rozenbergar et al. 2007; Stancioiu and O'Hara 2006). On the other hand, sycamore recruitment was more likely to occur in irregular stands. Sycamore is a light-dependent tree species (Petritan et al. 2007); therefore, this result was expected due to the higher light availability in the larger gaps in irregular stands. In contrast, the models of spruce recruitment occurrence showed no differences between stand types. One of the possible reasons is its wide light amplitude; it can be an even more shade-tolerant tree species than fir (Ferlin 2002), but in secondary succession it can also be a light-demanding pioneer species (e.g., Tjoelker et al. 2007).

The application of a particular silvicultural system can obviously influence the recruitment rate of tree species and hence the future tree species composition of forest stands (Malcolm et al. 2001; Yoshida et al. 2006; Kneeshaw and Prevost 2007; Raymond et al. 2009). The most likely reason for this seems to be differences in light availability and composition, which are closely related to canopy structure and gap size (e.g., Collet et al. 2001; Stancioiu and O'Hara 2006; Rozenbergar et al. 2007). In confirmation of our results, light-demanding sycamore in mixed old-growth forest in Bosnia and Herzegovina only recruited to pole-sized trees in canopy gaps $>0.044$ ha. Similarly, beech recruitment increased in openings $>0.04$ ha, while fir recruited highest in gaps $<0.04$ ha (Nagel et al. 2010). A similar pattern was found in balsam fir-yellow birch forests in Canada (Kneeshaw and Prevost 2007). Shade-tolerant balsam fir recruited abundantly in smaller gaps $(<0.02 \mathrm{ha})$, whereas shade-intolerant yellow birch recruited more successfully in larger openings $(>0.08 \mathrm{ha})$. The predominance of shadetolerant species regeneration and recruitment has also been reported in mixed irregular stands undergoing transformation to selection stands in Scotland (Cameron and Hands 2010). Contrary to our results, Yoshida et al. (2006) reported that selection silviculture in mixed forests in Japan promoted shade-intolerant broadleaved species to a larger extent than shade-tolerant coniferous and broadleaved species. A possible reason for contrary results is that the same silvicultural system can be applied in different ways. Gap size, stocking allocation, or management intensity can vary, significantly impacting the recruitment rate. Flexible forest management using a variety of silvicultural treatments and systems (Kneeshaw and Prevost 2007), similar to the "freestyle-silviculture" proposed by Mlinsek in Slovenia in the 1960s (Diaci 2006; Boncina 2011), maintains tree species of different shade tolerance, while a single silvicultural system may favor only one species or a group of tree species. Similarly, Malcolm et al. (2001) suggested a combination of group and single-tree selection systems with canopy gap areas $<0.05$ ha and a gap diameter to stand height $(\mathrm{d} / \mathrm{h})$ ratio $<1.0$ to promote shade-tolerant conifers, and group selection and irregular shelterwood systems with canopy gaps of $0.05-0.10$ ha and a $\mathrm{d} / \mathrm{h}$ ratio $\approx 1.0$ to promote less shade-tolerant coniferous species for transformation of artificial coniferous forests in Britain.

Site conditions are also important predictors of recruitment occurrence. Forest type as an indicator of different site conditions, such as competition from herbs and ferns, was found to be one of the most important predictors of the recruitment occurrence of fir, spruce, and beech. However, in addition to differences in site conditions, differences in silvicultural treatments and stand characteristics (Ficko et al. 2011) might be important. Among other site variables, soil $\mathrm{pH}$ was the most relevant. Low soil $\mathrm{pH}$ significantly increased the probability of recruitment occurrence of fir, spruce, and beech. Both conifer species are known to tolerate a wide range of soil acidity and to prosper on humus rich, medium fertile, moist, colder sites (Tjoelker et al. 2007), but beech similarly may have a wide tolerance.

The study unexpectedly revealed that the influence of forest stand mortality (natural and anthropogenic) was relatively minor. Tree mortality creates canopy gaps and reduces forest stand density and was therefore expected to have a greater influence on the recruitment rate than the models revealed. However, this result could be related to the problem of time lag (Lexerød 2005) since the recruitment rate depends on the conditions of several decades ago, while our data cover only the last 10 years. In selection fir-beechspruce forests, the time needed for trees to reach the measurement threshold size of $10 \mathrm{~cm}$ in dbh was determined to be 31 and 34 years on average with maximums of 100 and 95 years for fir and spruce, respectively (Ferlin 2002). This may be the reason that tree mortality and some site conditions (i.e., temperature, precipitation) were not found to influence recruitment occurrence as was expected.

The influence of large ungulate densities was also minor in our models although many studies have clearly demonstrated that large ungulates can have a major impact on the structure and composition of regeneration and recruitment (e.g., Gill 1992; Klopcic et al. 2010). The browsing rate on each tree species in the regeneration layer would probably be an informative variable to use in the modeling procedure, but this information was not available on the plot level. However, the negative influence of large ungulate densities on fir recruitment occurrence can be explained by fir's high palatability (Motta 1996). The influence of large ungulates on beech recruitment occurrence is not as clear since beech is considered to be a less palatable tree species (Gill 1992). A possible reason for the minor influence of large ungulates on recruitment occurrence as expected might be the time lag in relation to different spatial and temporal frameworks for data on both variables. The data on large ungulate 
densities may be appropriate and adequate for studying the influence of herbivores on regeneration (Gill 1992) but not for examining their influence on recruitment because of the long time frame that saplings need to escape the browsing height range of large ungulates and to reach the diameter measurement threshold.

Our study confirmed that there are noticeable differences in the recruitment rate of the main tree species between selection and irregular stands, even within the same forest type. Shade-tolerant fir and beech recruitment is more likely in selection stands, while recruitment of shade-intolerant sycamore is more likely in irregular stands. Moreover, high variability in recruitment abundance was observed within the same stand type. A partial explanation for this is that some stand parameters (e.g., harvesting gap sizes) can be influenced by silvicultural treatments. The variety of uneven-aged silvicultural systems and the many ways they can be applied provide a wide range of options for successful and efficient forest management.

Acknowledgments The authors would like to thank Slovenian Forest Service, especially Dragan Matijasic and Ales Poljanec, for providing the access to forest inventory data, which made our study feasible. The comments of the three anonymous reviewers significantly improved the earlier version of the manuscript.

Funding The study was supported in part by a grant from Pahernikova ustanova (contract number 11/2011).

\section{References}

Allison PD (1999) Logistic regression using SAS system: theory and application. SAS Institute Inc, Cary

Boncina A (2011) History, current status and future prospects of uneven-aged forest management in the Dinaric region: an overview. Forestry 84:467-478. doi:10.1093/forestry/cpr023

Brassel P, Lischke H (2001) Swiss National Forest Inventory: methods and models of the second assessment. WSL Swiss Federal Research Institute, Birmensdorf, Switzerland

Cameron AD, Hands MOR (2010) Developing a sustainable irregular structure: an evaluation of three inventories at 6-year intervals in an irregular mixed-species stand in Scotland. Forestry 83:469475. doi:10.1093/forestry/cpq029

Collet C, Lanter O, Pardos M (2001) Effects of canopy opening on height and diameter growth in naturally regenerated beech seedlings. Ann For Sci 58:127-134

Diaci J (2006) Gojenje gozdov: pragozdovi, sestoji, zvrsti, nacrtovanje, izbrana poglavja (in Slovene). Biotechnical faculty. Department for Forestry and Renewable Forest Resources, Ljubljana, Slovenia

Duc P (1991) Untersuchungen zur Dynamik des Nachwuchses im Plenterwald. Schweiz Z Forstwes 142:299-319

Ferlin F (2002) The growth potential of understorey silver fir and Norway spruce for uneven-aged forest management in Slovenia. Forestry 75:375-383. doi:10.1093/forestry/75.4.375

Ficko A, Poljanec A, Boncina A (2011) Do changes in spatial distribution, structure and abundance of silver fir (Abies alba Mill.) indicate its decline? For Ecol Manage 261:844-854. doi:10.1016/ j.foreco.2010.12.014
Gill RMA (1992) A review of damage by mammals in north temperate forests. 3. Impact on trees and forests. Forestry 65:363-388. doi:10.1093/forestry/65.4.363-a

Guisan A, Zimmermann N (2000) Predictive habitat distribution models in ecology. Ecol Model 135:147-186. doi:10.1016/S03043800(00)00354-9

Jerina K (2012) Roads and supplemental feeding affect home-range size of Slovenian red deer more than natural factors. J Mammal (in press)

Klopcic M, Jerina K, Boncina A (2010) Long-term changes of structure and tree species composition in Dinaric uneven-aged forests: are red deer an important factor? Eur J For Res 129:277-288. doi:10.1007/s10342-009-0325-z

Kneeshaw DD, Prevost M (2007) Natural canopy gap disturbances and their role in maintaining mixed-species forests of central Quebec, Canada. Can J For Res 37:1534-1544. doi:10.1139/x07-112

Lähde E, Laiho O, Norokorpi Y, Saksa T (2002) Development of Norway spruce dominated stands after single-tree selection and low thinning. Can J For Res 32:1577-1584. doi:10.1139/x02-075

Leinbundgut H (1952) Rolle und Grundlagen der Planung beim schweizerischen Femelschlag- und Plenterbetrieb. Allg Forstund Jagdzeitung 123:93-100

Lexerød N (2005) Recruitment models for different tree species in Norway. For Ecol Manage 206:91-108. doi:10.1016/j.foreco.2004.11.001

Lexerød N, Eid T (2005) Recruitment models for Norway spruce, Scots pine, birch and other broadleaves in young growth forests in Norway. Silva Fenn 39:391-406

Lundqvist L (2004) Stand development in uneven-aged sub-alpine Picea abies stands after partial harvest estimated from repeated surveys. Forestry 77:119-129. doi:10.1093/forestry/77.2.119

Malcolm DC, Mason WL, Clarke GC (2001) The transformation of conifer forests in Britain - regeneration, gap size and silvicultural systems. For Ecol Manage 151:7-23. doi:10.1016/S0378-1127 (00)00692-7

Mathews JD (1999) Silvicultural systems. Oxford University Press Inc, New York

Motta R (1996) Impact of wild ungulates on forest regeneration and tree composition of mountain forests in the Western Italian Alps. For Ecol Manage 88:93-98. doi:10.1016/S0378-1127(96)03814-5

Nagel T, Svoboda M, Rugani T, Diaci J (2010) Gap regeneration and replacement patterns in an old-growth Fagus-Abies forest of Bosnia-Herzegovina. Plant Ecol 208:307-318. doi:10.1007/ s11258-009-9707-z

Oliver CD, Larsen BC (1996) Forest stand dynamics. Wiley, New York

Petritan AM, von Lüpke B, Petritan IC (2007) Effects of shade on growth and mortality of maple (Acer pseudoplatanus), ash (Fraxinus excelsior) and beech (Fagus sylvatica) saplings. Forestry 80:397-412. doi:10.1093/forestry/cpm030

Raymond P, Bedard S, Roy V, Larouche C, Tremblay S (2009) The irregular shelterwood system: review, classification, and potential application to forests affected by partial disturbances. J For 107:405-413

Rozenbergar D, Mikac S, Anic I, Diaci J (2007) Gap regeneration patterns in relationship to light heterogeneity in two old-growth beech-fir forest reserves in South East Europe. Forestry 80:431443. doi:10.1093/forestry/cpm037

Schäffer A, Gazin A, d'Alverny A (1930) Sapinieres: Le jardinage par contenance (Methode du controle par les courbes). Presses Universitaire de France, Paris

Schütz JP (1975) Dynamique et conditions d'équilibre de peuplements jardinés sur les stations de la hêtraie à sapin. Schweiz Z Forstwes 126:637-671

Schütz JP (2001) Der Plenterwald und weitere Formen strukturierter und gemischter Wälder. Parey, Berlin, Germany

Schütz JP (2006) Modelling the demographic sustainability of pure beech plenter forests in Eastern Germany. Ann For Sci 63:93100. doi:10.1007/s10342-006-0111-0 
SFS (2010) Databases on forest stand characteristics and permanent sampling plots. Slovenia Forest Service, Ljubljana, Slovenia

Stancioiu PT, O'Hara KL (2006) Regeneration growth in different light environments of mixed species, multiaged, mountainous forests of Romania. Eur J For Res 125:151-162. doi:10.1007/s10342005-0069-3
Tjoelker MG, Boratiński A, Bugała W (2007) Biology and ecology of Norway spruce. Springer, Dordrecht

Yoshida T, Noguchi M, Akibayashi Y, Noda M, Kadomatsu M, Sasa K (2006) Twenty years of community dynamics in a mixed coniferbroad-leaved forest under a selection system in northern Japan. Can J For Res 36:1363-1375. doi:10.1139/x06-041 